Meta

Journal des traducteurs

Translators' Journal

\title{
Framing Brecht and the Greek Student Movement (1972-1973)
}

\section{Dimitris Asimakoulas}

Volume 54, numéro 2, juin 2009

URI : https://id.erudit.org/iderudit/037678ar

DOI : https://doi.org/10.7202/037678ar

Aller au sommaire du numéro

Éditeur(s)

Les Presses de l'Université de Montréal

ISSN

0026-0452 (imprimé)

1492-1421 (numérique)

Découvrir la revue

Citer cet article

Asimakoulas, D. (2009). Framing Brecht and the Greek Student Movement (1972-1973). Meta, 54(2), 233-247. https://doi.org/10.7202/037678ar

\section{Résumé de l'article}

Le présent article analyse la fonction subversive d'une anthologie des écrits politiques de Bertolt Brecht publiée en Grèce au moment de l'émergence du mouvement étudiant. La collection a été publiée en 1971, quatre ans après le coup d'État militaire en Grèce. Fondé sur la notion de cadre de la théorie des mouvements sociaux, l'article traite spécifiquement du parcours du mouvement d'étudiants grecs et des principaux cadres qui l'ont amené à être le type de résistance le plus efficace contre la junte. L'article fait en outre état de la façon dont l'anthologie de Brecht permet de mieux saisir le climat général d'opposition culturelle et politique qui a créé les conditions nécessaires au succès du mouvement étudiant. 


\title{
Framing Brecht and the Greek Student Movement (1972-1973)
}

\author{
DIMITRIS ASIMAKOULAS \\ The University of Surrey, Guildford, UK \\ asimakdimitris@yahoo.co.uk
}

\begin{abstract}
RÉSUMÉ
Le présent article analyse la fonction subversive d'une anthologie des écrits politiques de Bertolt Brecht publiée en Grèce au moment de l'émergence du mouvement étudiant. La collection a été publiée en 1971, quatre ans après le coup d'État militaire en Grèce. Fondé sur la notion de cadre de la théorie des mouvements sociaux, l'article traite spécifiquement du parcours du mouvement d'étudiants grecs et des principaux cadres qui l'ont amené à être le type de résistance le plus efficace contre la junte. L'article fait en outre état de la façon dont l'anthologie de Brecht permet de mieux saisir le climat général d'opposition culturelle et politique qui a créé les conditions nécessaires au succès $d u$ mouvement étudiant.
\end{abstract}

\section{ABSTRACT}

This paper examines the subversive function of an anthology of Bertolt Brecht's political essays that was published in Greece at the time the student movement was emerging. The collection was launched in 1971, four years after the military coup in Greece. Drawing on the notion of frame from social movements theory, the paper focuses on the trajectory of the Greek student movement and the main frames that brought it forward as the most successful form of resistance against the junta. Then the paper illustrates how the Brecht anthology in particular captures the general climate of cultural and political opposition that created the resonance deemed necessary for the success of the student movement.

\section{MOTS-CLÉS/KEYWORDS}

cadre, Brecht, Grèce, mouvements sociaux, sociologie, résistance

frame, Brecht, Greece, social movement, sociology, resistance

\section{Introduction}

Many approaches to translation have stressed the importance of seeing the act of translating as an activity that takes place in context. From the terminology and the overall register employed to reconstruct a text in a target language to the actual (and often unpredictable) effect on the readership, everything betrays the nature of translation as a social act. Translations are bound to be caught in networks of power relations simply because extratextual factors condition their creation and dissemination; yet the role of translation in social movements remains relatively uncharted territory by sociologists and translation studies scholars, with both sides often ignoring the significance of case studies and useful concepts in each field.

The starting point in this article is the student movement in Greece (1972-1973), a movement that was the catalyst for the overthrow of the Greek junta (1967-1974). The first part will illustrate that a fully-fledged opposition movement developed gradually: only certain opposition frames seemed to resonate with the masses of 
students and eventually the entire Greek society. Then the cultural field will be examined as it contributed to the genesis of such resistance frames. In the second part, a collection of Brecht's political essays will be seen against this backdrop. Both the selection of essays to be included as well as the way in which they were translated betray a broad concern with antidictatorship messages.

The reason why this particular historical period was chosen was the interrelation between resistance and cultural production became salient. More importantly, the role of translations was decisive. To sharpen the focus of this study the seven-year rule of the colonels must be seen in the light of the three stages it underwent (following Gregoriades [1975a]; [1975b]; [1975c]):

- 1967-1969, the rise of the regime allegedly in response to the danger of the country being taken over by communists; the period that represents its pinnacle of absolute control; preventive censorship was applied and all freedoms were curtailed.

- 1970-1973: stagnation, or the period of oscillation between sham liberalisation and a hard-line approach.

- 1973-1974: the downfall of the regime, which starts with the violent end of the student riots, the reimposition of censorship and martial law. This was a short-lived hard-line version of the junta.

As this division may signal, the Greek junta was not a monolithic, static entity. On an ideological level it exhibited features of fascist regimes (anti-communism, militarism, ultra-nationalism, (mild forms of) racialism, abolition of political parties and trade unions) yet unlike fascist regimes its propaganda was ineffectual, it never achieved a broad support basis, and it never redirected big capital to the national interest (Gregoriades 1975c: 347-350; Woodhouse 1985: 32). It was a regime that constantly oscillated between terror and a universalist pretension as saviours of the nation, between (intermittently applied) censorship and liberalisation. This creates a rather complex context but also points to significant transition points, the most important being the official lifting of censorship on November $15^{\text {th }}, 1969$ and what followed it.

\section{Framing the student movement}

A concept from general communication theory and social movement theory that can be fruitfully applied to the area of translation is the concept of frame (for a typology of framing from a narrative theory perspective in translation, see Baker 2006, chapter six). The term derives from the seminal work of Ervin Goffman Frame Analysis (1974) where "the organization of experience" is examined in a wide swath of human activity (ranging from televised wrestling matches to reader/audience participation in a novel or play). As Goffman notes:

I assume that definitions of a situation are built up in accordance with principles of organization which govern events - at least social ones - and our subjective involvement in them; frame is the word I use to refer to such of these basic elements as I am able to identify [...M] y phrase "frame analysis" is a slogan to refer to the examination in these terms of the organization of experience. (Goffman 1974: 10-11)

Frames can be keyed (based on a model/something already meaningful for participants but transformed into something else), fabricated (set up to be used for deception, either in a benign way or for the purpose of exploitation), or used in parallel 
with other (discrete) frames that may or may not be the main concern of the participants (employed to lead to out of the frame activity, in an act of collusion etc.) (Goffman 1974: 44, 84, 201). Interestingly, Goffman uses translation as an example of a keyed frame; a translation of a French play into English, as he claims, can be seen as an English transformation or keying of a French pattern of expression (Goffman 1974: 79).

Goffman's metaphor of frame has been revived in social movement theory where meaning construction and the interpretation of events and conditions are essential for guiding action, individual or collective (Snow et al. 1986: 464; Snow and Benford 2000: 613). It involves

assign[ing] meaning to and interpret[ing] relevant events and conditions in ways that are intended to mobilize potential adherents and constituents, to garner bystander support and to demobilize antagonists. (Snow and Benford 1988: 198)

The core functions of frames are diagnosis, prognosis and motivation. Diagnostic framing involves identifying the problem and attributing blame or causality to specific agents; prognostic framing suggests solutions to the problem, identifies strategies, tactics and targets; motivational framing offers a rationale for action, or inducements for participation, be they material, status, solidarity, or moral inducements (Snow and Benford 1988: 200-202). The three aspects of framing are usually closely interwoven. When combined, they motivate participation by convincingly distinguishing "insurgents ('us') from antagonists or irrelevant others ('them'), and by clearly representing the possibility, necessity, and efficacy of collective action by deliberate actors" (Polletta 1998: 140). Frames in social movements must also have resonance, if they are to be successful, that is, they need to be consistently articulated, to correspond with events in the world, and to be articulated by individuals who are credible and persuasive (Snow and Benford 2000: 619-621). Imbuing Goffman's abstract and static view of frames with a more active agential aspect of meaning creation and concentrating on the consumption aspect of frames (resonance) sheds light on the nature of social movements, yet remains incomplete if the most obvious and influential variable, cultural context, is left out. The larger cultural environment both enables and constrains potential movement meanings, simply because cultural context provides a repertoire of already packaged symbols, rhetoric and familiar forms of organization (Williams and Kubal 1999: 231, 232). Successful movement frames must have a cultural resonance if they are to succeed, namely, they must be in tune with frames and dominant themes in the cultural repertoire (alignment) and they must dominate the debate on a particular contested issue (efficacy) (Williams and Kubal 1999: 235).

The period of the Greek junta is an ideal testbed for such core concepts of social movements. The dominant modes of resistance and the cultural matrix in which they evolved can illustrate this point. Thus, resistance to the regime took various forms, but there is now consensus that specific factors jointly hampered attempts to develop a strong opposition movement immediately after the coup (Gregoriades 1975b: 276; Dafermos 2003: 142; Notaras 1999: 191): the political world had been caught by surprise and felt defeated after the coup, the regime perfected its persecution/policing mechanisms, living standards and purchasing power across a considerable section of Greek society were improving, and both citizens and resistance organizations were 
not optimistic that any single resistance strategy would topple the regime unless (international) conditions were right.

A great array of small left-wing resistance groups did form immediately after the coup, but their goal was to advertise everyone's reluctance to live under an authoritarian regime and to stir foreign public opinion against the dictatorship rather than to topple it. They were also very short-lived and arrests of key members meant the end of their activities. Their opportunistic nature can be seen in the great variety of tactics they employed and which ranged from circulating leaflets on the streets and publishing illegal newspapers to planting bombs in order to damage symbols of the regime (Woodhouse 1985: 36; Murtagh 1994: 175). The lack of effectiveness and mobilizing edge of resistance groups can also be attributed to the lack of co-operation among them. They were all divided and entrenched in the positions of the various left-wing political parties and organizations they shadowed (Dafermos 2003: 194).

The real turning point came with the student movement which emerged in 19721973, which was more successful than individual organizations and ultimately became the focus of the resistance effort of the entire country due to its resonance. This resonance can be attributed to the projection of what Williams and Kubal call a stewardship-cum-contractual frame, that is a notion of public good built upon the belief in collective duties, a responsibility to a community that is harmoniously connected on the one hand, and the belief in individual rights/inclusion in society on the other $(1999: 238,239)$. The components of these frames can be seen in the following characteristics of the movement: a) accommodation of views from political parties and the resistance organizations they supported, but independent development of the movement and democratic election of members of coordinating committees; b) the projection of a broad political agenda for the sake of the entire nation (responsibility) and pan-hellenic unity; c) demands for a return to democracy and the free expression of ideas; d) sense of moral superiority/dignity; e) denigration of the junta as a fascist regime that relied on violence and US support to exploit its people.

The student movement had a general left-wing orientation and various organizations supported by the banned KKE (the Greek Communist Party) and the centrist EK (Centre Union) political parties were associated with it, but their role remained ancillary. The overall mobilizing influence of the KKE influenced Regas Feraios and Anti-EFEE ('National Antidictatorship Student Union of Greece') and the EK inspired $P A K$ ('Panhellenic Freedom Movement') and DA ('Democratic Defence'), was intermittent or inherently weak, because such groups and their satellites disagreed on strategies and ideological agendas, or occasionally sought to impose their hierarchical view of organization, or - more significantly - they saw the developing movement as an expression of student syndicalism or class-related demands rather than as a mass antidictatorial political movement (Dafermos 2003: 195-208).

The broad popular appeal of the student movement became apparent because what initially started as a series of demands concerning academic life morphed into a more encompassing political discourse. It all started with grievances on the lack of funding for education and the strict control of syllabuses, appointments, and the language of instruction: the purist katharevousa variety was chosen instead of the demotike which had been gradually replacing it in other contexts (Woodhouse 1985: 126). The junta also dismantled virtually all representative bodies elected at the uni- 
versity and polytechnic level by the students themselves and appointed people who would help them control student unions (Murtagh 1994: 239). Initial demands for free student elections were followed by rhetoric focusing on the higher moral ground of the movement. Thus the mission of the student movement was "the national interests of Greece," "education," "freedom," all based on the belief in democratic processes; on the other hand, the junta was seen as an "anti-national enterprise," a regime that relied on violence and a total disregard for the law, and were singled out as fascists and agents of US interests (Regos 1999: 238; Dafermos 2003: 102, 124).

The agenda of the movement was clearly articulated and put into practice by a body that in essence represented all sectors of Greek society. Thus, in contrast to organizations that "called for resistance" and acted covertly, the student movement was democratically organized and resulted in actual initiatives and open confrontation with the authorities. In the spring of 1972, university schools, one after the other, set up their democratically elected FEAs "student struggle committees," securing a level of organization that carried the movement through the turbulent months of 1972 and 1973. First, all legal means were exhausted (student elections, class boycotts, taking cases to court) and when this failed, sit-ins, rallies, and riots were resorted to (Dafermos 2003: 196). The end of the movement came with the Athens Polytechnic sit-ins on November $17^{\text {th }}$, 1973, when the army violently quelled the movement and martial law came into effect.

The bloody ending of the student movement, and the supportive stance of all banned political parties dramatically increased its appeal. Unlike other movements in Western Europe at the time, the Greek student movement received the endorsement of all political parties in Greece, yet retained its independence from them and went on to challenge political and social values and to become the vehicle of expressing antidictatorial sentiments (Regos 1999: 228, 236, Dafermos 2003: 197). Bridging political divisions, it gained both the support and the participation of left-wing and conservative citizens. The feeling of unity that the student movement created resulted in a popular anti-dictatorship coalition of forces that ultimately destabilized and toppled the regime (Dafermos 2003: 196; Regos 1999: 246).

The overall successful framing of the student movement can be attributed to the cultural resonance it had. In order to see this, there is a need to examine the end of the first period of the junta (1967-1969) and the role of cultural activity and published translations because the very first signs of 'a' movement came from the cultural field. In June 1970 an influential organization was formed, EKIN (Helleno-European Youth Movement). This name signals Europe as a force of democracy - especially because Greece had left the Council of Europe in the face of its certain expulsion on charges of human rights violations (December $12^{\text {th }}, 1969$ ). The purpose of this group was to organize exhibitions and music events, to launch publications, to promote modern thought, and encourage the exchange of ideas (Dafermos 2003: 51; Regos 1999: 235). EKIN's members would later play a crucial role in the student movement and their activities found imitators (Regos 1999: 235; Dafermos 2003: 50). Given the failure of resistance organizations, this was the ground that would ideologically prepare activists for a fully-blown movement. It was the arena where an independent, new left ideology started to materialize, that is, left-wing ideas that did not necessarily emanate from the communist or the centrist party. Students and young people in general sought to project their own identity by reading translations of books on modern 
thought; they listened to banned popular music or music with clear political messages (such as Theodorakis) (Kouroupos 2002: 44, 45); they watched American subversive films such as Woodstock and participated in poetry nights; they attended dramatic performances such as those by the politicized Anoichto Theatro ("Open Theatre") and Theatro Technes ("Art Theatre") theatre companies, further boosting their popularity (Regos 1999: 232-235).

This "cultural spring" coincided with the end of censorship in 1969 as well as with the shift in tactics on the part of Greek authors and publishers with regard to censorship and oppression. Throughout the first period of the regime, the situation was highly unfavorable for literary and artistic production. The large majority of writers passively resisted censorship by refraining from producing any work. This "silence boycott" was legitimized by George Seferis, the 1963 Nobel Prize poet laureate, in his recorded anti-dictatorship message in Deutsche Welle in 28 March 1969 and was espoused by a considerable number of members of the Greek intelligentsia. Within a short time, however, an increasing number of writers and publishers realized that silence was convenient for the leaders of the military regime, who often advertised a broad and crude functional aesthetics in favor of art that was supposed to "serve the motherland" (Roufos 1972: 153). Publishing houses such as Kalvos and Keimena insisted that "silence was not as honourable as Seferis made it seem and that it was not fair to leave readers with the drivel and propaganda the regime's press office published" (Van Dyck 2002: 59). The culmination of this effort is the "resistance publication" Eighteen Texts ("Dekaokto Keimena" - July 1970), a collection of poems, short stories, and essays exploring issues of resistance and complicity, to which Seferis was one of the principal contributors. In this collection, which became a best seller, everything was communicated by innuendo, allegories, metaphors, and parodic attacks "hijacking" the dictators' routine patterns of speech (Van Dyck 2002: 80-97). The collective nature of the work was also intended to show that intellectuals from all political persuasions were united and that their action was not instigated by any one single political party (Papanikolaou 2002: 446). By abandoning the tactic of silence, writers asserted their sense of dignity, aesthetic autonomy and unity as well as their connection/duty to the Greek people). It was a time when freedom of speech was prioritized over any political creed (Regos 1999: 234).

Developments in the publishing field were very significant for the formation of the "contractual/stewardship frame" on a cultural level. After 1969 publishing activity was revitalized, with a dramatic increase of translated books in particular. There was an unprecedented demand for serious books or "problem books" (biblia problematismou) addressing critical social issues and bringing readers closer to modern European thought; the result was publication in translation of such authors as Herbert Marcuse, Antonio Gramsci, Jean-Paul Sartre, Arnold Hauser, Eugene Ionesco, and Bertolt Brecht (Kontogiannes 1970: 28-29; Kontogiannes 1971: 118 and Chatzopoulos 1971: n.p.). A large group of publishers emerged who saw as their duty the ideological awaking of Greek readers through literature, philosophy, literary theory, art, sociology and politics (Dafermos 2003: 29, Frankopoulos 1971: 89, and Soteropoulou 1997: 4). These publishing houses consisted of independent left-wing individuals because the authorities had already banned publishing houses with traditional left affiliations. They targeted students or older readers that were politically aware and who opposed the regime in an attempt to sharpen their critical thinking 
(Axelos 1984: 46; Soteropoulou 1997: 4). Bookstores became the loci where ideas were exchanged freely and where books became a means of ad hoc political, cultural, and artistic expression.

Although no clear-cut causal link between the above developments can be established, especially because they ran in parallel, the impression that remains is that there were some recurring themes in the public/cultural sphere after censorship was abolished. Students asserted their political and cultural independence, authors adopted a more vocal attitude and publishers supplied readers with politically subversive books. The ultimate goal was to overcome political division and passivity.

\section{Brecht's political texts reframed}

As was shown above, freedom of expression, unity and a focus on the "political other" that was the source of oppression were key elements in the student movement that had great cultural resonance. Now I would like to focus on a significant translated work that can be seen to echo this broader context of cultural/political resistance, an anthology of Brecht's political texts. For this purpose I need, once more, to resort to the notions of diagnosis, prognosis and motivation.

After the lifting of preventive censorship, Brecht became a very popular choice among publishers and a massive import of his works (mainly plays) commenced in 1970 (with 19 translations in 1970 alone, Greece produced more Brecht translations than either all of the Eastern Bloc countries or all Western countries did together in their peak years, 15 in 1962 and 17 in 1968 respectively). This popularity can perhaps be seen as an echo of the "Brecht boom" that started in 1968 in West Germany and which was a manifestation of the radicalisation of political conscience, mainly among the younger generations (Schneider 1979: 27). Brecht became the centrepiece of the student movement and the New Left movement in Germany at the time (Mittenzwei 1977: 78; Schneider 1979: 26; Patterson 2001: 276). Brechtian social criticism was dominant in the German cultural field - which incidentally included intellectuals that wrote "fiery poems against the Greek junta" (Schneider 1979: 28, my translation). The German and Greek student movements coincided temporally and Greeks had also already fled to Germany to escape oppression and directly experienced the political and cultural developments there. These individuals may have served as channels that communicated political and cultural trends across borders. This, of course, includes translators. Anna Koltsidopoulou, for instance, was in Germany when she translated Mann ist Mann. She subsequently sent her manuscript to Greece and the book was published in Athens in 1971 by the politically engaged and prolific Planetes Publications.

Brecht publications in Greece (mainly plays) were immediately identified as good examples of "problem books" (see previous section) that can awaken the country (Kontogiannes 1970: 29; Frankopoulos 1971: 89). In 1971 Stochastes Publications brought out Politika Keimena ("Political Texts"). The collection exclusively consists of essays Brecht wrote during his exile period in Europe (1933-1941), that is, the period when Brecht dissected Nazism and suggested means of resistance. Nazism was, according to Brecht, the "most naked, brazen, oppressive and deceitful capitalism" (Brecht 1993: 35, my translation). Similarly, fighting the evils of fascism was seen to entail going to the root of the problem, that is, property relations as well as 
unraveling obscurantist fascist discourse (Knopf 2003: 264-270). Brecht also underscored the need to effectively defend culture with politico-economic means and insisted that the Nazis had no intention of minimizing violence and war-mongering in the future (Knopf 2003: 266). These diagnostic, prognostic and motivational aspects in Brecht's writing reflect a strictly Marxian perspective that emerged in a context of (imminent) war. Yet the collection of essays in Greek translation were framed differently, both because of the outlet of this publication as well as the ways in which the texts were translated.

Politika Keimena ("Political Texts," thereafter PT) was translated by Dionyses Divares under the pseudonym of Vasiles Vergotes. Divares was born in 1952 and studied law at The University of Athens. Two years after the publication of the book he was involved in the student movement (the sit-ins in the Law School February $21^{\text {th }}$, 1973) and was generally familiar with the methods of harassment employed by the authorities. Divares was drawn to Stochastes because the publishing house stood out as a place where progressive and anti-dictatorship ideas were expressed but without drawing the immediate attention of the regime (Divares, personal communication, September $\left.20^{\text {th }}, 2004\right)$. Divares used a pseudonym at the publisher's advice in order to minimize his visibility. He believed that a collection of texts from Brecht's political essays would constitute a bold political statement, "at a time of intellectual darkness" as he called it (personal communication, September $20^{\text {th }}, 2004$ ).

Stochastes was founded by a young law graduate, Loukas Axelos in 1969. For Stochastes publications were a means of political and cultural communication (Axelos 1984: 46). The choice of titles to launch at the time is indicative of this main concern. Stochastes focused on political books. The first book they published in 1969 was Keimena ("Texts") by Regas Feraios Velestinles, the ideologue of The Greek Enlightenment Movement (1770-1829) and the Greek War of Independence (1821). The fact that Stochastes, like many influential publishers (such as Kalvos Publications, Keimena Press, Epikairoteta) followed the selfsame pattern of reviving texts from the same epoch can be seen as a symbolic gesture of diagnosis (equating the obscurantism of the junta with that of a foreign occupation force, the Ottomans), prognosis (advocating intellectual awakening and militancy as means of defeating tyranny) and motivation (showing that the political situation was a matter of national survival). Generally speaking, Stochastes had two objectives (Soteropoulou 1996: n.p.): to create the conditions that would lead to the overthrow of the colonels and to disseminate the progressive leftist ideology that did not necessarily subscribe to the traditional Leninist tradition of the old Greek Communist Party. Thus, all the Stochastes publications signal rigorous political engagement: essays by prominent Greek thinkers (Dimitris Glenos, Alexandros Svolos, Serafeim Maximos), and translations of works by Herbert Marcuse (the so-called father of the New Left in Europe and a vocal supporter of the student movements throughout the 1960s), by Nazim Hikmet (the communist Turkish poet who was imprisoned, persecuted and forced to flee Turkey), by Antonio Gramsci, by Asiz Nesin (the Turkish socialist author and political activist who also confronted the authorities and was sent to prison) and, of course, Bertolt Brecht.

It is because of the abovementioned beliefs of the agents of translation as well as the general political climate of the time that Brecht's works were likely to have been recontextualised. Indeed the texts can be grouped according to their diagnosis, 
prognosis, and mobilizing function vis-à-vis the authoritarian context in Greece. As concerns the diagnostic aspect, essays such as "Fascism and Capitalism" (1935), "Source of Every Barbarism" (1937) and the two speeches given at the first and second “International Writers' Congress for the Defence of Culture” $(1935,1937)$ are good examples. These texts describe how the fascist regime in Germany (but also Italy and Spain) persecuted, physically abused and killed dissenters, suppressed freedom of speech, changed the processes of production and served dominant class interests. Fascists waged an all-out war on culture too, because culture has a material basis. Fascism, as the most abject form of capitalism, relies heavily on property ownership and therefore violence to remain in power. Such themes/frames could only resonate with readers who experienced the oppressive practices of the junta in their daily lives. For instance, in Fascism and Capitalism (1935), Brecht deplores the fact that "intellectual workers" do not resort to "a cry of wrath" when fourteen communist newspapers were banned. He concludes by saying (close/literal translations from the German and Greek are my own):

Die Polizei verbietet die Wahrheit, und die Zeitungen bezahlen die Lüge! (Brecht 1993: 106)

The police forbids the truth and the newspapers pay (for) the lies!

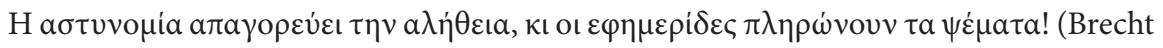
1971: 55)

The police forbids truth and newspapers pay for lies!

The silencing of the press and the reluctance of cultural producers to raise their voice in protest were highly relevant issues for readers who lived in a police-controlled Greek state at the time. Very often the use of active voice in the translation accentuates this diagnostic function as is systematically done in the first "International Writers' Congress for the Defence of Culture" (1935):

Warum [ist] das Leben von Millionnen Menschen, der allermeisten Menschen so verarmt, entblößt, halb oder ganz vernichtet? (Brecht 1967: 242)

Why is the life of millions of people, of most people thus impoverished, bared, or annihilated by half or completely?

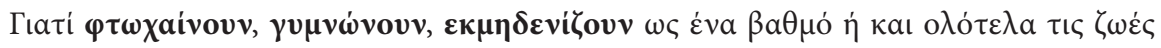

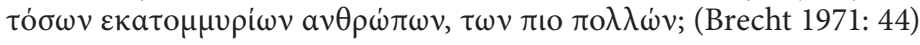

Why do they impoverish, strip and annihilate to a certain extent or completely the lives of so many millions of people, of the most (of them)?

Opaque agents of the ST are thus forced to the foreground of the Greek text. Oppressive regimes rely on violence and censorship to remain in power.

Other essays in the collection fulfil mainly a prognostic framing function: "Five Difficulties in Writing the Truth" (1934), "In Times of Weakness" (date uncertain), "On Restoring the Truth" (1934) and "In the Fight Against Injustice Even Weak Weapons are of Use" (1934). Brecht argues that even "weak" means of resistance, as he calls them, such as protesting injustice, raising one's voice against oppressors and participating in small or large organisations that fight injustice, can have a significant effect. The entire collection offers ways of addressing one of the main concerns of Brecht's thought and art, namely, the exercise of critical thinking. The most powerful form of prognostic framing occurs in the longest essay in the collection, "Five 
Difficulties in Writing the Truth." The text was initially published in an émigré journal in 1934 and was clandestinely distributed to as broad a readership as possible in Germany (Crick 2000: 123). According to Knopf, it constitutes the highest achievement of all exile literature written in German; it had a massive appeal for antifascist authors in Germany and abroad (and was translated into Polish and Danish in 1935) (2003: 273, 274). The text constitutes a classic Marxist contribution to the development of an aesthetic of resistance; it is concerned with the truth of literature, with the capacity of art to contribute to political struggle (Kuhn and Giles 2003: 119). A good example from "Five Difficulties in Writing the Truth" that promotes critical thinking is the following:

Eine Betrachtugsweise, die das Vergängliche besonders hervorhebt, ist ein gutes Mittel, die Unterdrückten zu ermutigen... Die Abhängigkeit jedes Dings von vielen andern, sich ständig ändernden, ist ein den Diktaturen gefährlicher Gedanke, und er kann in vielerlei Arten auftreten, ohne der Polizei eine Handhabe zu bieten. (Brecht 1993: 86-87)

An observation manner, that stresses the transient, is a good means to courage the oppressed... the dependence of everything on many others, which constantly change, is a dangerous thought to dictatorships, and can be found in many forms, without giving the police a lever.

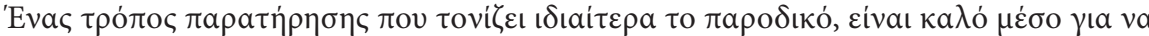

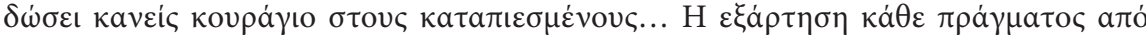

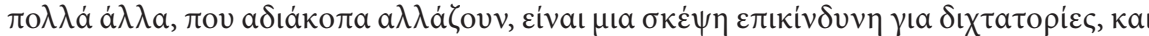

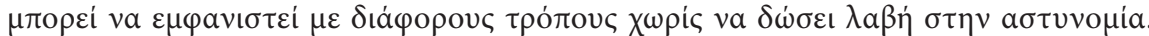
(Brecht 1971: 24)

A way of observing things that shows the ephemeral in particular is a good means of giving courage to the oppressed... the dependence of everything on other things that are constantly changing is a dangerous thought for dictatorships and can manifest itself in many ways, without giving the police a lever.

This excerpt suggests the tactical use of discourse that undermines the worldview of a dictatorship. Brecht notes that dictatorships favour a static and dogmatic perception of reality, and it is change and progress that they fear the most. Such themes must have struck a chord with Greek citizens and intellectuals at the time; this was a period when passive consumerism prevailed and the media were turned into mouthpieces of the regime, but it was also the period when grievances started to be expressed in various areas: new translations of ancient Greek drama foregrounded the idea of tyrannicide (Van Steen 2001: 151-171), Greek cinema was intensely anti-neorealist and politically subversive (Katsounake 2002: 35) and the publishing industry gravitated around the "ideological awakening" of Greek readers with translated political books (Soteropoulou 1997: 4).

The prognostic function is occasionally brought to the fore by means of more salient changes on the Greek version, with the strategic use of inclusive we's as can be seen in the concluding statement from "Five Difficulties in Writing the Truth" and the first speech at the "International Writers' Congress for the Defence of Culture":

Soviel wird verlangt, wenn verlangt wird, der Schriftsteller soll die Wahrheit schreiben. (Brecht 1993: 89)

So much is demanded, when (it) is demanded that writers should write the truth. 


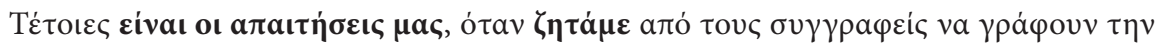
$\alpha \lambda \dot{n} \theta \varepsilon ı$. (Brecht 1971: 26)

Such are our requirements, when we ask authors to write the truth.

Man wird aufspringen und den Peinigern in den Arm fallen. (Brecht 1967: 241)

One will jump up and grapple with the torturers.

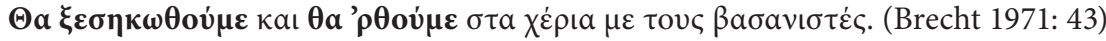

We will rise and we will grapple with the torturers/tormentors.

Such shifts - which can be found in many of the collection's essays - focus on the steps that need to be taken in the fight against oppression, but also project a fused plural-self. In the original, passives and impersonal constructions imply Brecht and his readers/listeners. In the TT the author's voice clearly merges with that of the translator and the Greek readers in inclusive we's. Thus rhetorical participation in the argument is enacted in a more direct way, admonitions become more forceful, and common ground is established.

This brings us to the last framing task, motivation. Motivational framing in the book has authors in general as its target and indirectly, of course, generic readers. Certain passages present authors with the challenge of arriving at a thorough understanding of the core of fascism, that is, dominant class interests and property ownership - as is noted in the concluding section of "The Five Difficulties in Writing the Truth." Once they achieve this understanding and take on the task of spreading truth among those who suffer the most under fascism, they can begin to initiate change in society. In his 'Speech at the Second International Writers' Congress for the Defence of Culture" (1937), Brecht underscores the moral duty of intellectuals to dismiss fascism and wage their war on it. The urgency of declaring this sort of war is justified on the grounds that fascist wars that serve the privileges of the few show no signs of abatement. Another essay, “The Basic Duty of Anti-Fascist Writers" (1937), makes an appeal to all anti-fascist writers to intensify their fight against fascism:

In dieser Zeit zunehmender Verwirrung ist es eine Hauptaufgabe der antifaschistischen Schriftsteller, den Sinn für die Trennung des Wichtigen vom Unwichtigen zu schärfen. Wichtig aber ist allein der umfassende, mit allen Mitteln geführte, unermüdliche Kampf gegen den Faschismus auf breitester Grunglage. (Brecht 1993: 332)

In this time of increasing confusion it is the primary duty of the antifascist authors to sharpen the sense of separating the important from the unimportant. Important is only the all-encompassing, led-with-every-means, unrelenting struggle against fascism, in its broadest base.

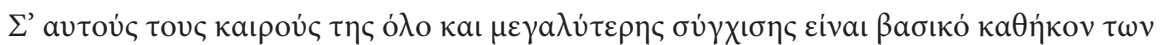

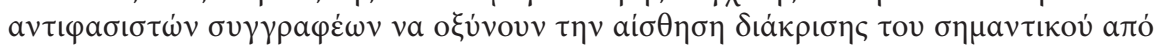

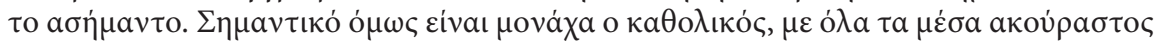

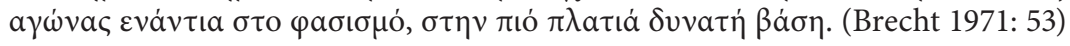

In these times of increasing confusion it is the basic duty of antifascist writers to sharpen the sense of separating important from unimportant things. What is important is the all-encompassing unrelenting struggle with every means against fascism with the broadest base (of support) possible.

Again the essay elaborates issues that are highly topical in the Greek context: the role of intellectuals as a force that can awaken society and the need to participate in the fight against fascism irrespective of political persuasion. The wider the base of antifascist/antidictatorial forces, the more effective the struggle will be. 
Perhaps a more indirect way of mobilizing readers is the employment of shifts in style. There are certain features in the translation that increase the accessibility of the texts. Thus, all essays exhibit a very frequent use of contractions (

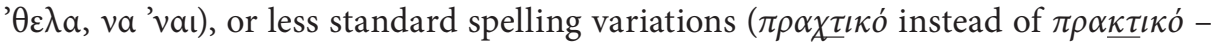

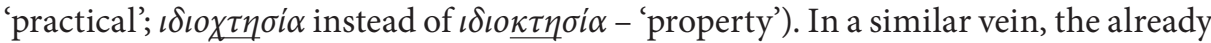
down-to-earth style of Brecht's writing is accentuated in the TT with the use of more colloquial words (die Habe (possessions) > to ßıৎ (possessions[+coll.]); die Methoden

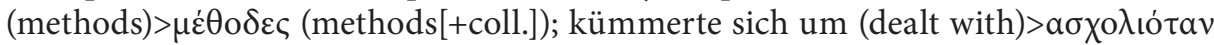
(dealt with[+inf.]); ungleichmäßig (disproportionately)>avıøó $\mu \varepsilon \rho a$ (disproportionat ely[+coll.])). The cumulative effect of such shifts is the increase of the tone of directness or the 'speakability' of the text. Brecht is in a sense brought closer to the reader and speaks their everyday language, that is, spoken demotike. This strategy of signalling in-groupness can be seen to sharply contrast with the translator's code-switching technique in Brecht's critical (and mocking) deconstruction of the discourse of Nazi officials, such as the Nazionalzeitung article on the triumph over communism in Germany by Hermann Göring (December $12^{\text {th }}, 1934$ ). The translator employs katharevousa, the purist variety of Greek championed by the junta for Göring's speech (katharevousa structures marked in the Greek version):

Die deutsche Regierung muß sich vorbehalten, in völliger Freiheit die Mittel anzuwenden, die sie für richtig hält, und sie kann dabei auf fremde Ratschläge keine Rücksicht nehmen. (Brecht 1993: 91)

The German government must reserve for itself (the right) in total freedom to use the means, that it considers appropriate, and, in that it, it can take no consideration of the advice of others.

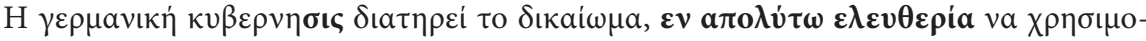

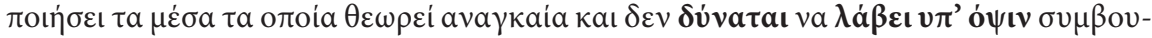

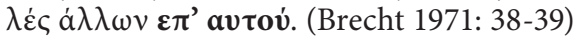

The German government reserves the right, in full freedom [inflection, prepositional phrase] to use the means that it considers (to be) necessary and cannot take into account the advice on others on this [verb+prepositional phrase, prepositional phrase].

Speeches and addresses to the people were very common when the book was published in Greece, especially because the media were under government control. The translator seems to mimic such publicity forays. By using katharevousa he equates Nazi officials with the colonels in Greece, a common denigration/mobilising strategy at the time. The implicit message conveyed through this technique is that the Greek regime is comparable to Nazism and will have a similar fate, that is, it will fall and its enormities will be exposed by the oppressed and morally superior Greek citizens and by the international community in general.

\section{Conclusion}

This paper has focused on the complex relation between translation and social change in an authoritarian context. One of the main reasons why the Greek junta collapsed in July 1974 was the mounting hostile attitude of Greek citizens of every persuasion. The catalyst of this development was the student movement, a movement to which all Greek citizens could relate (and more so than to the agendas of individual resistance organizations). It was a movement that was democratically organized, stressed 
the importance of collective duty to society and advocated the right to free expression/dignity vis-à-vis a ruthless dictatorship. These were resistance frames that resonated with the Greek population, irrespective of political persuasion. They were also frames that were the result of a transformative fusion of forces after the official lifting of censorship in 1969. Indeed this was a period during which authors, publishers and students developed homologous activity that underscored the need for unity before the common enemy of Greek society, the regime. Authors abandoned their tactic of silence; students pursued their rights to free student elections and asserted their cultural values; publishers inundated the book market with subversive political books in translation.

Continuities of this sort are crucial if translation activity is to be studied in depth in a situation where social groups have dissimilar access to power. Frames focusing on the source of oppression (diagnosis), the means/agents to counter it (prognosis) and the urgency/duty to resist it (motivation) were articulated in the field of cultural production in the first instance and subsequently within the remit of a fully-fledged social movement. As was argued in this paper, it was the dynamics of cultural resonance the post-1969 situation created that allowed the student movement to be so popular. Translation played an indispensable part in this ideological preparation of resistance. It was translations of the so-called serious problem books that became the vehicles of resistance frames.

A prime example of such resistance publications is the anthology of political essays by Bertolt Brecht launched by Stochastes. As was argued, the notion of framing can be used as a means of seeing the (re)contextualization of the essays contained in the anthology with respect to the translator's/publisher's new left ideals and overall political engagement. It can also be used as a tool of analysis to shed light both on the very selection of text thematics, as well as on the shifts in the final product according to their diagnostic, prognostic and motivational function.

The tentative application of this model for the Greek context can perhaps be extended to other situations where social movements were facilitated by translation action, contexts where translation can be seen as a social act that can materialize in such diverse behaviors as the sheer opening of publishing houses or the promotion of a particular political view by discursive - although not exclusively textual - activity. The abundance of movements (student, environmentalist, feminist, gay rights etc.) as well as the invisible contribution of translations of various kinds (political texts, philosophy, sociology, journalistic texts and - the more extensively studied - literary texts) lay bare the methodological and historical importance of further work along these lines.

\section{REFERENCES}

Axelos, Loukas (1984): Ekdotike drasterioteta kai kinese ton ideon sten Hellada [Publishing activity and circulation of ideas in Greece]. Athens: Stochastes.

Benford, Robert D. and Snow, David A. (2000): Framing processes and social movements: an overview and assessment. Annual Review of Sociology. 26: 611-639.

BAKer, Mona (2006): Translation and Conflict. A Narrative Account. London: Routledge.

BRECHT, Bertolt (1967): Gesammelte Werke in 20 Bänden. Band 18. Frankfurt am Main: Suhkamp Verlag.

Brecht, Bertolt (1971): Politika Keimena [Political Texts] (Translated by Vasiles Vergotes). Athens: Stochastes. 
BRECHT, Bertolt (1993): Werke: Bertolt Brecht. Große kommentierte Berliner und Frankfurter Ausgabe (Edited by Werner Hecht et al.), Berlin: Aufbau Verlag.

Chatzopoulos, Giorgos (1971): Ti diabazei he semerine neolaia. Protase gia te dimeourgia hellenikou kentrou bibliou [What today's youth read. Suggestion for the creation of a Greek Book Centre]. To Vima: n.p. July 29, 1971.

CRICK, Joyce (2000): Difficulties with the truth in the Svendborg Poems. In: Roland SPEIRs, ed. Brecht's Poetry of Political Exile. Cambridge: CUP, 114-134.

DAfermos, Olympios (2003): To antidiktatoriko foitetiko kinema 1972-1973 [The Anti-Dictatorship Student Movement 1972-1973]. Athens: Gabrielides.

Frankopoulos, Theodoros (1971): Biblia 1970: mia apotimese [Books 1970: an overview] Chroniko 1971: 88-91.

Goffman, Ervin (1974): Frame Analysis. Middlesex: Penguin.

Gregoriades, Solon (1975a): Historia tes diktatorias 1967-1974. Tomos los Epivole kai akme [History of the Dictatorship 1967-1974. Vol. 1. Establishment and heyday]. Athens: Ekdoseis Kapopoulos.

Gregoriades, Solon (1975b): Historia tes diktatorias 1967-1974. Tomos 2os Apotelmatosis [History of the Dictatorship 1967-1974. Vol. 2. Stagnation]. Athens: Ekdoseis Kapopoulos.

Gregoriades, Solon (1975c): Historia tes diktatorias 1967-1974. Tomos 3os He katarreusis [History of the Dictatorship 1967-1974. Vol. 3. Collapse]. Athens: Ekdoseis Kapopoulos.

Katsounake, Maria (2002): To festival Thessalonikes kai he anthese tou neou hellenikou kinematografou [The Thessalonike Film Festival and the Burgeoning of New Greek Cinema]. Polites. 99: 34-36.

Knopf, Jan (2003): Zu Politik und Gesellshaft. In: Jan KNopf, ed. Brecht Handbuch. Band 4: Schriften, Journale, Briefe. Stuttgart: Verlag J. B. Metzler, 262-272.

Kontogiannes, Giorgos (1970): Biblia problematismou sten prote gramme tes ekdodikes kineses [Problem books on the lead of publications]. Chroniko 1970: 118-119.

Kontogiannes, Giorgos (1971): He ekdotike kinese tes chronias [Publications report of the year]. Chroniko 1971: 118-119.

Kouroupos, Giorgos (2002): He protoporiake mousike sten Hellada sta chronia tes diktatorias [Avant-Garde Music in Greece in the Junta Years]. Polites. 99: 44-47.

Kunn, Tom and Giles, Steve, eds. (2003): Brecht on Art and Politics. London: Methuen.

Mittenzwei, Werner (1977): Wer war Brecht? Aufbau: Berlin.

Murtagh, Peter (1994): The Rape of Greece. The King, the Colonels and the Resistance. London: Simon and Schuster.

Notaras, Gerasimos (1999): Diktatoria kai organomene antistase [Dictatorship and organised resistance]. In: Gianna Athanasatou, Alkes Regos and Serafeim Seferiades, eds., He Diktatoria 1967-1974. Politikes Praktikes, Ideologikos Logos, Antistase [The Dictatorship 1967-1974: Political Practices. Ideological Discourse. Resistance]. Athens: Kastaniotes, 187-198.

Papanikolaou, Dimitris (2002): He techne tes cheronomias: ksanadiavazontas ta Dekaokto Keimena [The art of gesturing: rereading the anti-dictatorship Collection $18 \mathrm{Texts}$ ]. Nea Hestia. 1743: 444-460.

Patterson, Michael (2001): Brecht's legacy. In: Peter Thomson and Glendyr Sachs, eds. The Cambridge Companion to Brecht. Cambridge: CUP, 273-287.

Polletta, Francesca (1998): "It Was like a Fever..." Narrative and identity in social protest. Social Problems. 45(2): 137-159.

Regos, Alkes (1999): Foitetiko kinema kai diktatoria [The Student Movement and the Dictatorship]. In Gianna Athanasatou, Alkes Regos and Serafeim Seferiades (eds), He Diktatoria 1967-1974. Politikes Praktikes, Ideologikos Logos, Antistase [The Dictatorship 1967-1974: Political Practices. Ideological Discourse. Resistance]. Athens: Kastaniotes, 224-251.

Roufos, Rodis (1972): Culture and the military. In: Richard ClogG and Giorgos Yannopoulos, eds. Greece Under Military Rule, London: Secker and Warburg, 146-162. 
SCHNEIDER, Michael (1979): Bertolt Brecht - Ein abgebrochener Riese. Zur ästhetischen Emanzipation von einem Klassiker. Literaturmagazin 10: Vorbilder. 10: 25-64.

Snow, David A. et al. (1986): Frame alignment processes, micromobilization, and movement participation. American Sociological Review Vol. 51: 464-481.

Snow, David A. and Robert D. Benford (1988): Ideology, Frame Resonance, and Participant Mobilization. International Social Movement Research. 1: 197-217.

Soteropoulou, Mariana (1996): Diadromes tou politikou bibliou sten Hellada 1967-1974. [The course of political books in Greece 1967-1974]. Athens: Ethniko Kentro Vivliou.

Soteropoulou, Mariana (1997): To politiko biblio ste diarkeia tes diktatorias 1967-1974. Erevna kai bibliografike katagrafe [Political books during the dictatorship 1967-1974. Study and bibliographic record]. Athens: Ethniko Kentro Vivliou.

VAN Dyck, Karen (2002): He Kassandra kai oi logokrites sten hellinike poise 1967-1990 [Kassandra and the Censors in Greek Poetry 1967-1990] (Translated by Palmyra Ismyridou). Athens: Agra.

Van Steen, Gonda (2001): Playing by the Censors' Rules? Classical Drama Revived under the Greek Junta (1967-1974). Journal of the Hellenic Diaspora. 27(1-2): 133-194.

Williams, Rhys H. and Kubal, Timothy J. (1999): Movement frames and the cultural environment. Resonance, failure, and the boundaries of the legitimate. Research in Social Movements, Conflicts and Change. 21: 225-248.

Woodhouse, Christopher Montague (1985): The Rise and the Fall of the Colonels, London: Granada. 